\title{
Bioactive compounds in gladiolus flowers
}

\author{
Alexandra Goede de Souza ${ }^{1 *}$ (), Eduardo Affonso Jung ${ }^{1}$ (D), Vinícius Petermann Benedicto ${ }^{1}$ (D), Leosane Cristina Bosco $^{2}(\mathbb{D}$ \\ ${ }^{1}$ Instituto Federal Catarinense, Rio do Sul-SC, Brazil. \\ ${ }^{2}$ Universidade Federal de Santa Catarina, Curitibanos-SC, Brazil.
}

\begin{abstract}
Flowers have received special attention not only for their ornamental nature but also for their nutraceutical, cosmetic, aromatic, and culinary properties. This study aimed to characterize physicochemical attributes and the antioxidant capacity of flowers of four gladiolus cultivars. The cultivars used were White Friendship, Rose Supreme, Jester, and T704. We analyzed the content of total soluble solids (SS), total titratable acidity (TA), SS/TA ratio, $\mathrm{pH}$, vitamin $\mathrm{C}$, anthocyanin, flavonoids, total phenolic compounds (TPC), total antioxidant activity (TAA), and the relationship of TPC with flavonoids and TAA for each cultivar. The results showed that the Jester flowers had the lowest TA and highest SS/TA ratio, indicating the best flavor. Jester also had the highest flavonoid content, similarly to the White Friendship and Rose Supreme. As a result, these cultivars have flowers with higher TPC and TAA content than T704. The anthocyanin content was the characteristic attribute of cultivar T704, due to its purple pigmentation. Gladiolus flowers, traditionally used in landscaping and as cut flowers, have the potential for use in human nutrition, particularly the White Friendship, Rose Supreme, and Jester cultivars.
\end{abstract}

Keywords: Gladiolus x grandiflorus Hort.; edible flowers; cut flowers; antioxidant activity.

\section{Resumo}

\section{Compostos bioativos em flores de gladíolo}

As flores vêm recebendo atenção especial, não apenas por seu uso ornamental, mas também pelas suas propriedades nutracêuticas, cosméticas, aromáticas e culinárias. O objetivo deste estudo foi caracterizar os atributos físicos equímicos e a atividade antioxidante em flores de quatro cultivares de gladíolo. As cultivares utilizadas foram White Friendship, Rose Supreme, Jester e T704. Analisaram-se conteúdo de sólidos solúveis totais, acidez titulável total, relação entre SS/AT, pH, vitamina C, antocianina, flavonoides, compostos fenólicos totais, atividade antioxidante total e a relação entre compostos fenólicos totais e flavonoides e compostos fenólicos totais e atividade antioxidante total para cada cultivar. Os resultados mostraram que as flores do cultivar Jester têm menor acidez titulável total e maior relação sólidos solúveis totais/acidez titulável total, indicando o melhor sabor. A Jester também teve o maior teor de flavonoides, não diferindo da White Friendship e Rose Supreme. Em consequência, essas cultivares têm flores com maior conteúdo de compostos fenólicos totais e maior atividade antioxidante total que a T704. O conteúdo de antocianina foi o atributo característico do cultivar T704, dada a pigmentação de suas flores. As flores de gladíolo, tradicionalmente empregadas no paisagismo e como flor de corte, têm potencial de uso na alimentação humana, com destaque para as cultivares White Friendship, Rose Supreme e Jester.

Palavras-chave: Gladiolus x grandiflorus Hort.; flores comestíveis; flores de corte; atividade antioxidante.

\section{Introduction}

Many plants, besides their ornamental value, have flowers with characteristics that make them attractive to human consumption (Lim, 2014; Chitrakar et al., 2019), raising the interest in their cultivation not only for decorative purposes but also as food. Floraphagia, the use of flowers in the human diet, has been known for hundreds of years and is associated with the emergence and development of human civilization worldwide (Albán et al., 2018). However, only in recent years, edible flowers have gained space in contemporary cuisine. Such an increase in flower consumption is mainly attributed to the beauty of its shapes, colors, and aromas, ensuring sophistication to elaborated dishes (Fernandes et al., 2016;Acikgoz, 2017; Albán et al., 2018). Research studies also point out that flowers have

*Corresponding author: alexandra.souza@ifc.edu.br 
high nutritional value, being considered functional and nutraceutical (Skrajda, 2017; Amarante et al., 2019).

Many flowers, such as nasturtium, pansies, marigold, fuchsia (Benvenuti et al., 2016), feijoa (Amarante et al., 2019), pot marigold, rose, elder, starflower, and mauve (Chitrakar et al., 2019), have medicinal properties due to the presence of bioactive compounds. Among the bioactive compounds, phenols stand out for their high antioxidant capacity, besides their minerals and vitamins (GonzálezBarrio et al., 2018), contributing to improving the quality of life (Gonçalves et al., 2019; Suram, 2020). However, despite their potential, the consumption of edible flowers is still under suspicion due to people's fear of trying new foods (Benvenuti et al., 2016). On the other hand, the growing search for healthy, nutritionally complete, and pleasant-looking foods has been driving the consumption of foods considered unconventional (Mlcek and Rop, 2011). Therefore, these foods must be recognized and identified, ensuring the safety of consumers. In this scenario, it is also essential to consider that flowers destined for the ornamental market are not for consumption, since they were not produced for this purpose and may pose health risks due to the use of pesticides in phytosanitary management. Thus, flowers produced in an agroecological or organic manner should be preferred (Fernandes et al., 2016).

Among the flowers considered edible and with medicinal properties, the gladiolus (Gladiolus x grandiflorus Hort.) stands out (Lim, 2014; Acikgoz, 2017; Suram, 2020). It is an important cut flower, extensively cultivated throughout the world, which has gone through a long hybridization process, ensuring a wide variety of colors. This herbaceous plant is characterized by a spike-shaped inflorescence, containing 12 to 20 florets and corms annually renewed (Lim, 2014; Schwab et al., 2019). Due to its easy cultivation, short cycle, and variety of colors, in Brazil, the production of the species as a cut flower is intensifying in small rural properties, becoming a source of diversification in family farming (Uhlmann et al., 2019). The use of gladiolus flowers in the human diet represents an important marketing alternative for farmers, boosting the added value of their products. Also, they can be an important and healthy nutritional source (Matraszek-Gawron et al., 2019) and be used as a natural colorant in the food industry (Islam, 2016).

Studies on the use of gladiolus flowers in human nutrition, their nutritional characteristics, and health benefits are inexistent in Brazil and rare worldwide. Some results found in the literature report characteristics of gladiolus flowers, such as anthocyanin contents (Akavia et al., 1981; Takemura et al., 2008;Lim, 2014;Islam, 2016), antioxidant capacity, and phenolic content ( $\mathrm{Li}$ et al., 2014). Considering the arguments above and the nutritional potential of gladiolus flowers, this study aimed to generate information on physicochemical attributes and the antioxidant capacity of flowers of four gladiolus cultivars produced in Brazil. We hypothesize that organicproduced gladiolus flowers have nutraceutical or bioactive properties, with potential for use in human nutrition.

\section{Material and Methods}

The gladiolus cultivars White Friendship, Rose Supreme, Jester, and T704 (Figure 1) were organically produced in

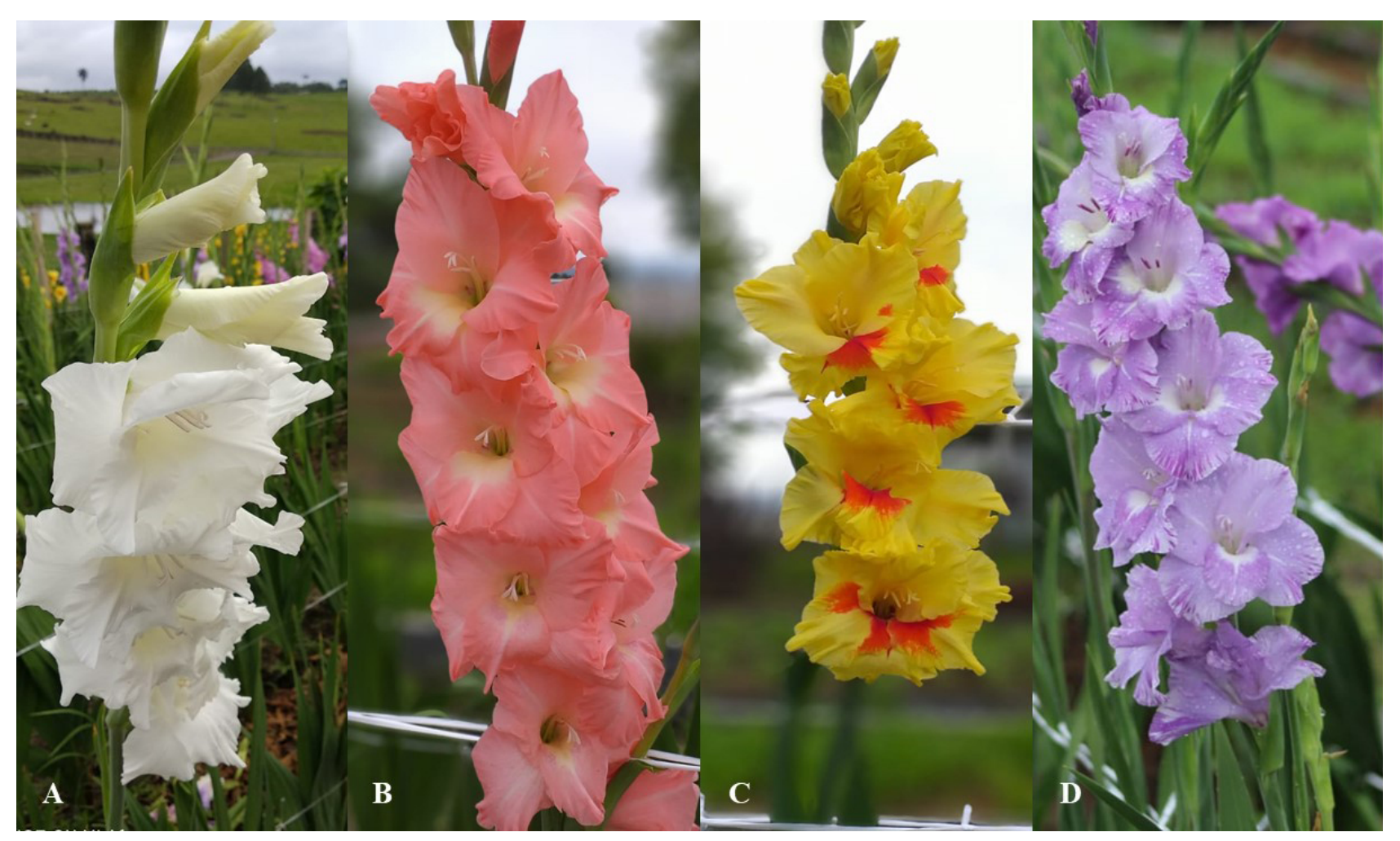

Figure 1. Gladiolus floral stems with open florets. Cultivars: (A) White Friendship; (B) Rose Supreme; (C) Jester; (D) T704. 
an experimental area of the Instituto Federal Catarinense (IFC), Campus Rio do Sul, SC (latitude 2711'16", longitude 49'39'22", and altitude $673 \mathrm{~m}$ ). The climate is Cfa-subtropical humid with hot summers -, the annual mean temperature is $18^{\circ} \mathrm{C}$, and the soil is classified as Haplic Cambisol (ClimaDate.org, 2020). The cultivation and management of the plants followed the recommendations for the culture (Schwab et al., 2019) with adaptations. The experiment was conducted from August to November 2019.

The corms were planted in a $5 \mathrm{~m}$ long and $1 \mathrm{~m}$ wide bed for each cultivar, with $40 \mathrm{~cm}$ between rows and $20 \mathrm{~cm}$ between plants. Cultivation was carried out in the open and without irrigation. The average monthly precipitation and maximum and minimum temperatures in the period were, respectively, $125.75 \mathrm{~mm}, 21.18^{\circ} \mathrm{C}$, and $14.12^{\circ} \mathrm{C}$ (IFC weather station). Soil $\mathrm{pH}$ was adjusted to 6.0 , according to the soil analysis.

The statistical design used was completely randomized, with four treatments (cultivars) and three replications, and each repetition consisted of 20 flowers. Data were submitted to statistical analysis, considering the premises of their normality and homogeneity variance. The analysis of variance used the Tukey test to identify statistical differences between treatments at a 5\% level of error probability. Data were processed in the statistical software SASM-Agri (Canteri et al., 2001).

The harvest of flower stems was carried out manually early in the morning of the R3.4 stage (when half of the stem florets were open) (Schwab et al., 2019), and they were immediately transported to the plant physiology and post-harvest laboratory. In fully-open flowers, we analyzed soluble solids (SS), total titratable acidity (TA), SS/TA ratio, $\mathrm{pH}$, vitamin $\mathrm{C}$ content, anthocyanin, flavonoids, total phenolic compounds (TPC), and total antioxidant activity (TAA). Analyses were performed on the juice of flowers of each treatment, extracted with a mixer (Arno Turbomix model).

The SS content of the juice was measured in a digital refractometer (RTD-95). TA content was obtained by titrating $5 \mathrm{~mL}$ of flower juice diluted in $45 \mathrm{~mL}$ of distilled water with sodium hydroxide $0.1 \mathrm{~N}$ up to the turning point (Instituto Adolfo Lutz, 2008); the results were expressed as percentage of citric acid. The SS/TA ratio was calculated by dividing SS by TA. The $\mathrm{pH}$ of the juice extracted from the flowers (Instituto Adolfo Lutz, 2008) was determined with a benchtop $\mathrm{pH}$ meter (model mPA210).

Vitamin $\mathrm{C}$ content was determined by the spectrophotometricmethod, using2.4-dinitrophenylhydrazine (2.4-DNPH) (Amarante et al., 2019). We used $1 \mathrm{~g}$ of the sample macerated in $50 \mathrm{~mL}$ of oxalic acid $(0.5 \%)$. After filtration, $1 \mathrm{~mL}$ of the sample was added to $3 \mathrm{~mL}$ of oxalic acid, five drops of the oxidizing agent 2.6 dichlorophenolindophenol (2.6-DCFI), $1 \mathrm{~mL}$ of 2.4-DNPH, one drop of thiourea, and $5 \mathrm{~mL}$ of sulfuric acid. The readings were taken in a spectrophotometer at $520 \mathrm{~nm}$, and the results were expressed as $\mathrm{mg}$ of ascorbic acid per $100 \mathrm{~g}^{-1}$ of fresh mass (FM).

The flowers were ground and homogenized with an extracting solution (ethanol 95\%: $\mathrm{HCl} 1.5 \mathrm{~N}-85: 15$, $\mathrm{v} / \mathrm{v}$ ) and stored for 12 hours at $4^{\circ} \mathrm{C}$ to determine the total anthocyanin and flavonoid contents. The samples were filtered with a paper filter, and absorbance was measured in a spectrophotometer at the electromagnetic wavelength $(\lambda)$ of $535 \mathrm{~nm}$ for anthocyanins and $374 \mathrm{~nm}$ for flavonoids (Amarante et al., 2019). The results were expressed as mg per $100 \mathrm{~g}^{-1}$ of fresh matter, calculated by Equation 1:

Anthocyanin or Flovonoids $=\frac{\text { Absorbance } * \text { dilution factor }}{76.6(\text { for flavonoids }) \text { or } 98.2(\text { for anthocyanin })}$

The procedure to obtain hydroalcoholic extract for the quantification of TPC and TAA was described by Amarante et al. (2017). For the extraction, $10 \mathrm{~g}$ of processed flowers were soaked in 50\% methanol solution for one hour. Next, the material was centrifuged at $5.000 \mathrm{rpm}$ for 30 minutes. The supernatant was stored, and the residue was submitted to a new extraction with acetone $70 \%$. After one hour, the material was centrifuged again, adding the supernatant to the previous sample, completing the volume of $100 \mathrm{~mL}$ with distilled water.

TPC quantification was performed by the FolinCiocalteu colorimetric method, which involves reducing the reagent by phenolic compounds of the sample, forming a blue complex that linearly increases the absorbance at $\lambda$ of $760 \mathrm{~nm}$ (Amarante et al., 2017). Gallic acid was used as a TPC standard. We removed $2.5 \mathrm{~mL}$ of the extract and added $7.5 \mathrm{~mL}$ of distilled water. In a dark environment, $1 \mathrm{~mL}$ of the diluted extract was obtained, followed by the addition of $1 \mathrm{~mL}$ of Folin-Ciocalteu, $2 \mathrm{~mL}$ of $20 \%$ sodium carbonate, and $2 \mathrm{~mL}$ of distilled water. Readings were taken in triplicate, after 30 minutes, in a spectrophotometer at $\lambda$ of $760 \mathrm{~nm}$. The spectrophotometer was calibrated using white. The TPC content of the flowers was expressed as gallic acid equivalent (GAE; mg GAE $\mathrm{g}^{-1} \mathrm{FM}$ ), using the straight-line equation obtained from the calibration of the curve with gallic acid.

TAA was determined using the methodology based on the capacity of the extract to sequester the radical 1.1-diphenyl2-picrylhydrazyl (DPPH method) (Lara-Cortés et al., 2014). In a dark environment, $0.1 \mathrm{~mL}$ of the extract was used with $3.9 \mathrm{~mL}$ of the DPPH radical (in triplicate). The mixture was shaken in a Vortex and left to rest. The readings were taken in a spectrophotometer at $\lambda$ of $515 \mathrm{~nm}$, after 30 minutes. Methyl alcohol was used to calibrate the spectrophotometer (Rayleigh UV-9200). The inhibition rate of the DPPH radical was calculated using Equation 2:

$I(\%)=\frac{\left(A_{\text {white }}-A_{\text {sample }}\right)}{A_{\text {white }}} \times 100$

in which:

$\mathrm{A}_{\text {white }}=$ absorbance of the control reaction (contains all reagents, except the tested sample);

$\mathrm{A}_{\text {sample }}=$ absorbance of the tested sample.

\section{Results and Discussion}

Gladiolus flowers showed no differences in SS content among cultivars, with a mean value of 5.3 (Table 1). 
Table 1. Total soluble solid (SS; \%) content, total titratable acidity (TA; \%), SS/TA ratio, and pH in flowers of different gladiolus cultivars*.

\begin{tabular}{|l|c|c|c|c|c|c|}
\hline Attributes & $\begin{array}{c}\text { White } \\
\text { Friendship }\end{array}$ & $\begin{array}{c}\text { Rose } \\
\text { Supreme }\end{array}$ & Jester & T704 & Mean & CV (\%) \\
\hline SS & $5 \mathrm{a}$ & $5.6 \mathrm{a}$ & $5.8 \mathrm{a}$ & $4.9 \mathrm{a}$ & 5.3 & 7 \\
\hline $\mathrm{TA}$ & $0.22 \mathrm{a}$ & $0.22 \mathrm{a}$ & $0.18 \mathrm{~b}$ & $0.21 \mathrm{a}$ & 0.21 & 7 \\
\hline $\mathrm{SS} / \mathrm{TA}$ & $22.7 \mathrm{~b}$ & $25.4 \mathrm{~b}$ & $32.2 \mathrm{a}$ & $23.3 \mathrm{~b}$ & 25.9 & 10.3 \\
\hline $\mathrm{pH}$ & $4.3 \mathrm{a}$ & $4 \mathrm{a}$ & $4.1 \mathrm{a}$ & $4.3 \mathrm{a}$ & 4.2 & 1.3 \\
\hline
\end{tabular}

*Values followed by the same letter in the rows do not differ according to the Tukey test $(\mathrm{p}<0.05)$; CV: coefficient of variation.

These values are lower than those reported for feijoa and nasturtium flowers $-11.75 \%$ and $7.80 \%$ - (Silva et al., 2018; Amarante et al., 2019), indicating that gladiolus flowers present low sweetness.

The mean TA found in the flowers was $0.21 \%$, with the lowest acidity detected in the Jester cultivar (Table 1). TA results are lower than those reported for the edible flowers daylily and rainbow pink - $0.31 \%$, and $0.35 \%$, respectively (Stefaniak and Grzeszczuk, 2019); however, they are similar to those found in nasturtium (Costa et al., 2014). Thus, gladiolus flowers can be considered lowacid vegetables, showing greater potential for consumer acceptance.

The flowers had a mean SS/TA of 25.9, with higher values for the Jester cultivar (32.2), while no differences were identified between the other cultivars (Table 1). The highest SS/TA ratio of the Jester cultivar can be attributed to the flower having the lowest TA value. In a study conducted in Poland with five different edible flowers, except gladiolus, the SS/TA ratio ranged from 3.79 to 18.08 (Stefaniak and Grzeszczuk, 2019), lower values than those reported in this research. The SS/TA ratio is an indication of the organoleptic quality of the food; the higher the value, the better the taste. Thus, gladiolus flowers have attributes of better taste compared to other species, with the Jester cultivar having more pleasant characteristics than the others. However, the perception of taste does not depend only on one factor but on how the taste is perceived by human receptors, which involves appearance, size, color, shape, and texture. In general, sweetness is associated with a most pleasant flower taste (Mlcek and Rop, 2011), which results from the higher sugar content or lower acidity, leading to higher SS/TA ratios.

The $\mathrm{pH}$ did not differ among the gladiolus cultivars, with a mean value of 4.2 (Table 1). These values are similar to those reported for rose 'Carola' petals - 3.94 (Moreira et al., 2020).

Gladiolus cultivars showed no effects on vitamin $\mathrm{C}$ content, with a mean value of $22.7 \mathrm{mg} 100 \mathrm{~g}^{-1} \mathrm{FM}$. These values are lower than those reported for pansies (256 mg $100 \mathrm{~g}^{-1} \mathrm{FM}$ ), red nasturtium (129 and $60.9 \mathrm{mg}$ $\left.100 \mathrm{~g}^{-1} \mathrm{FM}\right)$, daylily (75.98 $\left.\mathrm{mg} 100 \mathrm{~g}^{-1} \mathrm{FM}\right)$, and rainbow pink (89.78 $\mathrm{mg} 100 \mathrm{~g}^{-1} \mathrm{FM}$ ) (Costa et al., 2014; Fernandes et al., 2016; Stefaniak and Grzeszczuk, 2019). However, similar contents were found in feijoa $(25.2 \mathrm{mg}$
$100 \mathrm{~g}^{-1} \mathrm{FM}$ ), begonia (30.4 mg $100 \mathrm{~g}^{-1} \mathrm{FM}$ ), and cauliflower (30.7 mg $\left.100 \mathrm{~g}^{-1} \mathrm{FM}\right)$; the values were also higher than those of broccoli (Fernandes et al., 2016; Amarante et al., 2019).

Vitamin C is important for the maintenance of the human immune system, the health of the skin, gums, and blood vessels, the prevention of scurvy, and as an antioxidant (Lee and Kader, 2000). Since it is not produced by the human body, it needs to be ingested, and vegetables are the main sources of this vitamin. The recommended daily intake (RDI) of vitamin $\mathrm{C}$ established for adults in Brazil is $45 \mathrm{mg}$ (Brasil, 2005), while FAO/WHO recommends 75 $\mathrm{mg}$ (Fernandes et al., 2016). So, a daily intake of $100 \mathrm{~g}$ of gladiolus flowers provides $50 \%$ of the RDI of this vitamin in Brazil, and $30 \%$ by $\mathrm{FAO} / \mathrm{WHO}$, indicating that they are important sources of this vitamin in the human diet.

Anthocyanin contents ranged from 0.5 (White F.) to 13.9 (T704) mg $100 \mathrm{~g}^{-1}$ FM (Table 2). The higher values of anthocyanin in T704 may be related to the color of this cultivar (lilac/purple). The color of flowers is directly related to the quantity and quality of anthocyanin present in gladiolus flowers (Akavia et al., 1981; Takemura et al., 2008; Islam, 2016) and other vegetables (Cortez et al., 2017). In different gladiolus genotypes cultivated in the United States, the highest total anthocyanin content was found in red flowers, followed by pink and violet cultivars (Islam, 2016). In dahlias, anthocyanin content has a high correlation (0.982) with the color of the flower. The closer to purple, the greater the anthocyanin content, and the closer to white, the lower the content (Lara-Cortés et al., 2014). In a study assessing several flowers, the anthocyanin content varied from 2.8 to $58.9 \mathrm{mg} 100 \mathrm{~g}^{-1} \mathrm{FM}$, with the highest values in orange nasturtium and pansies, and the lowest in ora-pro-nobis and green-cauliflower (Gonçalves et al., 2019).

The amount of anthocyanin in the T704 cultivar is higher than in feijoa (7.7 mg $\left.100 \mathrm{~g}^{-1} \mathrm{FM}\right)$, pot marigold (0.47 mg $\left.100 \mathrm{~g}^{-1} \mathrm{FM}\right)$, fuchsia (7.58 mg $\left.100 \mathrm{~g}^{-1} \mathrm{FM}\right)$, and orange nasturtium (8.27 mg $100 \mathrm{~g}^{-1} \mathrm{FM}$ ) (Benvenuti et al., 2016; Amarante et al., 2019). However, similar contents were reported for important edible flowers, such as bluepansies (13.6 mg $100 \mathrm{~g}^{-1} \mathrm{FM}$ ) and red (12.4 mg $\left.100 \mathrm{~g}^{-1} \mathrm{FM}\right)$ and red petunia (14.4 mg $100 \mathrm{~g}^{-1} \mathrm{FM}$ ) (Benvenuti et al., 2016). The consumption of flowers depends on several factors, including coloring. Colorful and/or more intense colored flowers tend to be more appreciated by consumers (Cortez 
Table 2. Contents of vitamin C, anthocyanin, flavonoids ( $\mathrm{mg} 100 \mathrm{~g}^{-1} \mathrm{FM}$ ), total phenolic compounds (TPC; $\mathrm{mg} \mathrm{GAE} \mathrm{g}^{-1} \mathrm{FM}$ )*, and total antioxidant activity (TAA; \%) in flowers of different gladiolus cultivars**.

\begin{tabular}{|l|c|c|c|c|c|c|}
\hline Attributes & $\begin{array}{c}\text { White } \\
\text { Friendship }\end{array}$ & $\begin{array}{c}\text { Rose } \\
\text { Supreme }\end{array}$ & Jester & T704 & Mean & CV (\%) \\
\hline Vitamin C & $23.7 \mathrm{a}$ & $21 \mathrm{a}$ & $21.7 \mathrm{a}$ & $24.6 \mathrm{a}$ & 22.7 & 10.7 \\
\hline Anthocyanin & $0.5 \mathrm{c}$ & $2.4 \mathrm{~b}$ & $3.5 \mathrm{~b}$ & $13.9 \mathrm{a}$ & 5.1 & 7.8 \\
\hline Flavonoids & $52.1 \mathrm{a}$ & $49.1 \mathrm{a}$ & $46.3 \mathrm{a}$ & $35.8 \mathrm{~b}$ & 45.8 & 5.8 \\
\hline TPC & $146.1 \mathrm{a}$ & $136.1 \mathrm{~b}$ & $138.8 \mathrm{~b}$ & $127.5 \mathrm{c}$ & 137.1 & 2.7 \\
\hline TAA & $93.1 \mathrm{a}$ & $92.9 \mathrm{a}$ & $92.7 \mathrm{a}$ & $91.1 \mathrm{~b}$ & 92.6 & 0.4 \\
\hline
\end{tabular}

${ }^{*} \mathrm{GAE}{ }^{-1} \mathrm{FM}$ : gallic acid equivalent per gram of fresh mass; **values followed by the same letter in the rows do not differ according to the Tukey test $(\mathrm{p}<0.05)$; CV: coefficient of variation.

et al., 2017). In this regard, gladiolus flowers of the cultivars T704, Jester, and Rose S.show great potential for human consumption, as their intense colors give a special aspect to dishes. Among the few studies conducted with gladiolus, we can highlight those performed by Akavia et al. (1981) and Islam (2016). These researchers detected, from chromatography analyses, different types of anthocyanins in gladiolus cultivars. These compounds originated the following anthocyanin pigments: pelargonidin, cyanidin, delphinidin, peonidin, and malvidin. The pink-colored Rose Supreme cultivar predominantly has pelargonidin in its petals; in violet cultivars, the presence of delphinidin, peonidin, and malvidin was identified (Akavia et al., 1981). Cultivars with white and green petals showed no type of anthocyanin (Islam, 2016).

The mean content of total flavonoids was $45.8 \mathrm{mg}$ $100 \mathrm{~g}^{-1} \mathrm{FM}$, with higher values in White F., Rose S., and Jester, which did not differ from each other, followed by T704 (Table 2). Similar values were reported for green cauliflower, ora-pro-nobis, and red nasturtium - 33.5, 34.6, and $64.7 \mathrm{mg} 100 \mathrm{~g}^{-1} \mathrm{FM}$, respectively (Gonçalves et al., 2019). Feijoa has shown values between 8.19 and $12.18 \mathrm{mg} 100 \mathrm{~g}^{-1} \mathrm{FM}$ depending on the cultivar (Amarante et al., 2019), while in orange nasturtium and pansies, the

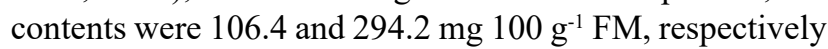
(Gonçalves et al., 2019). These values are higher than those of many fruits considered important for nutrition (Savi et al., 2017), such as apple (12.1 mg $\left.100 \mathrm{~g}^{-1} \mathrm{FM}\right)$, tomato

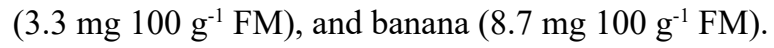

Besides the esthetic aspect, flowers with a high level of flavonoid and anthocyanin content have more functional properties. Nevertheless, in this study, flowers with higher anthocyanin contents did not present higher flavonoid values. In this case, the levels of flavonoid content in the cultivars White F., Rose S., and Jester should be attributed to other substances, not quantified in this study, such as flavones or flavonols. In a study carried out by Corrêa et al. (2015), the authors found that Brazilians' average daily consumption of flavonoids is $138.92 \mathrm{mg}$. An adequate RDI has not been established, but some investigations point out the importance of the regular intake of flavonoids since they are related to a wide variety of biological activities, especially antioxidant, anti-inflammatory, antitumor, antiallergic, and antiviral ones, among others (Savi et al., 2017).
The main sources of flavonoids described in the literature include vegetables, fruits, and grains (Skrajda, 2017); thus, considering alternative sources such as gladiolus flowers is essential.

Gladiolus flowers showed high TPC content with a mean value of $137.1 \mathrm{mg}$ GAE $100 \mathrm{~g}^{-1} \mathrm{FM}$ (Table 2). The cultivars showed differences in TPC, especially White F., with the highest value (146.1 mg GAE $100 \mathrm{~g}^{-1}$ FM), followed by Jester (138 mg GAE $100 \mathrm{~g}^{-1} \mathrm{FM}$ ), Rose S. (136 mg GAE $100 \mathrm{~g} \mathrm{~g}^{-1} \mathrm{FM}$ ), and T704, with the lowest value (127.5 mg GAE $\left.100 \mathrm{~g}^{-1} \mathrm{FM}\right)$. In Gladiolus hybridus, the TPC was $230 \mathrm{mg}$ GAE $100 \mathrm{~g}^{-1} \mathrm{FM}$ (Li et al., 2014), higher than the levels found in the cultivars of Gladiolusx grandiflorus in this study. However, the TPC of gladiolus flowers was superior to other edible flowers, such as rainbow pink, feijoa, nasturtium, rose and marigold (Navarro-González et al., 2015; Amarante et al., 2019; Stefaniak and Grzeszczuk, 2019). These TPC values demonstrate that gladiolus flowers are a potential source of TPC, considered phytochemicals with multiple functions, including antioxidant activity (Chensom et al., 2019).

The data show that flavonoids contribute to higher TPC contents, as can be observed in the White F. cultivar, which presented the highest values of TPC and total flavonoids, while T704 presented lower values of flavonoids and TPC, resulting in a significant positive linear relationship between TPC and flavonoids ( $\mathrm{R}=0.7125)$ (Figure 2A).

All flowers presented high TAA (DPPH method), with a mean value of $92 \%$ (Table 2). The flowers of the cultivars White F., Rose S., and Jester showed higher DPPH radical inhibition capacity, without differences between them, while the T704 presented the lowest inhibition capacity. The TAA of gladiolus flowers was superior to those reported for snapdragon flowers and similar to pansies and rose 'Carola' petals (González-Barrio et al., 2018; Moreira et al., 2020).

The antioxidant activity is attributed mainly to the presence of TPC. Many studies have shown the positive relationship between TAA and TPC contents in several vegetables (Li et al., 2014; Amarante et al., 2019; Chensom et al., 2019). In this study, flowers of cultivars with the highest TAA (White F., Rose S., and Jester) also had the highest TPC content, and the cultivar with the lowest TPC content (T704) presented the lowest TAA, resulting in a significant positive linear relationship $(\mathrm{R}=0.7561)$ 


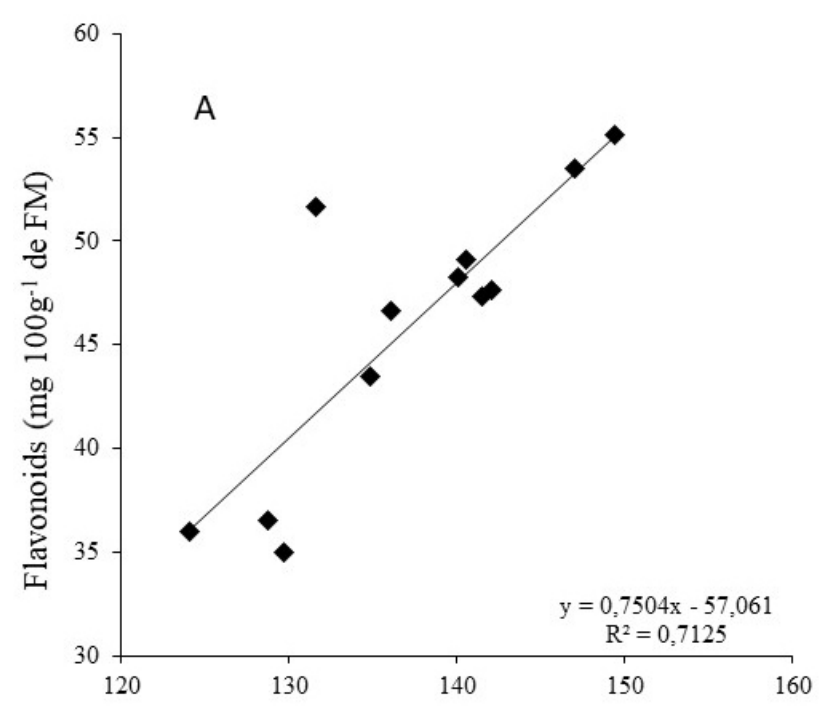

Total phenolic compounds (mg EAG g-1 of FM)

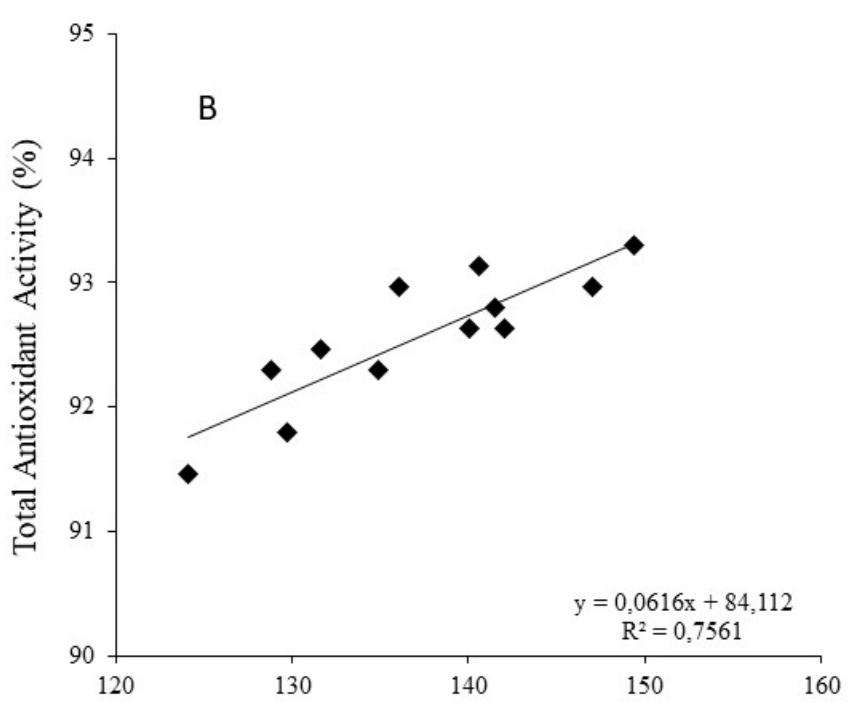

Total phenolic compounds (mg EAG g-1 of FM

FM: fresh mass; GAE: gallic acid equivalent; DPPH: 1.1-diphenyl-2-picrylhydrazyl.

Figure 2. Relationship of (A) total phenolic compounds with total flavonoid content and (B) the DPPH radical inhibition capacity in flowers of four different gladiolus cultivars.

between TPC and TAA (Figure 2B). These results indicate that phenolic components may be the main controllers of antioxidant activities in gladiolus flowers.

Despite the advances in research, little is still known about the functional potential of edible flowers, considered non-traditional food (Benvenuti et al., 2016). In this regard, the information generated in this study is essential to understand that gladiolus flowers can be considered edible, with a high content of anthocyanins, flavonoids, and natural antioxidants. The flowers that are currently cultivated for ornamental purposes can also be grown organically for use in human nutrition, being a potential nutraceutical food that should be explored in the prevention of problems arising from the oxidative stress of cells.

Besides adding nutritional value to the food, the results obtained in this work can boost the production and consumption of gladiolus flowers, which are currently an alternative in promoting the expansion and diversification of the production in rural family properties.

\section{Conclusion}

Flowers of gladiolus cultivars can be considered a functional food since they have a high SS/TA ratio, as well as high vitamin $\mathrm{C}$ content, anthocyanins, flavonoids, and TPC. Also, these flowers have high antioxidant activity, attributed to the great DPPH radical sequestration capacity.

\section{Author contribution}

AGS: Conceptualization, funding acquisition, investigation, data curation, project administration, supervision, validation, writing, review and editing. EAJ and VPB: Conceptualization, investigation, methodology, formal analysis, validation, writing original draft. LCB: Writing, review and editing.

\section{Acknowledgments}

The authors acknowledge the Fundo Nacional de Desenvolvimento da Educação (FNDE) for the financial support, theIFC-Campus Rio do Sul and the PhenoGlad team for their support in the execution of the project.

\section{References}

ACIKGOZ, F.E. Edible flowers. Journal of Experimental Agriculture International, v.17, n.1, p.1-5, 2017. https:// doi.org/10.9734/JEAI/2017/34564

AKAVIA, N.; STRACK, D.A.; COHEN, A. The coloration of Gladiolus I. Survey of anthocyanins in petals of Gladiolus. Zeitschrift für Naturforsch, v.36, p.378-382, 1981. https://doi.org/10.1515/znc-1981-5-605

ALBÁN, M.S.; ECHAVARRÍA, P.E.; DOMÍNGUEZ, L.D. Composición nutricional y propiedades funcionales de flores comestibles. Saber, v.30, n.1, p.498-507, 2018.

AMARANTE, C.V.T.; SOUZA, A.G.; BENINCÁ, T.D.T.; STEFFENS, C.A. Phenolic content and antioxidant activity of fruit of Brazilian genotypes of feijoa. Pesquisa Agropecuária Brasileira, v.52, n.12, p.1223-1230, 2017. https://doi.org/10.1590/S0100204X2017001200011 
AMARANTE, C.V.T.; SOUZA, A.G.; BENINCÁ, T.D.T.; STEFFENS, C.A.; CIOTTA, M.N. Physicochemical attributes and functional properties of flowers of Brazilian feijoa genotypes. Pesquisa Agropecuária Brasileira, v.54, e-00445, 2019. https://doi.org/10.1590/s1678-3921. pab2019.v54.00445

BENVENUTI, S.; BORTOLOTTI, E.; MAGGINI, R. Antioxidant power, anthocyanin content and organoleptic performance of edible flowers. Scientia Horticulturae, v.199, p.170-177, 2016. https://doi.org/10.1016/j.scienta.2015.12.052

BRASIL. Ministério da Saúde. Agência Nacional de Vigilância Sanitária (ANVISA). Resolução RDC n 269, de 22 de setembro de 2005. Aprova o regulamento técnico sobre a ingestão diária recomendada (IDR) de proteína, vitaminas e minerais. Diário Oficial da União, Poder Executivo, Brasília, 2005.

CANTERI, M.G.; ALTHAUS, R.A.; VIRGENS FILHO, J.S.V.; GIGLIOTI, E.A.; GODOY, C.V. SASM - Agri: Sistema para análise e separação de médias em experimentos agrícolas pelos métodos Scoft - Knott, Tukey e Duncan. Revista Brasileira de Agrocomputação, v.1, n.2, p.18-24, 2001.

CHENSOM, S.; OKUMURA, H.; MISHIMA, T. Primary screening of antioxidant activity, total polyphenol content, carotenoid content, and nutritional composition of 13 edible flowers from Japan. Preventive Nutrition and Food Science, v.24, n.2, p.171-178, 2019. https://doi. org/10.3746/pnf.2019.24.2.171

CHITRAKAR, B.; ZHANG, M.; BHANDARI, B. Edible flowers with the common name "marigold": Their therapeutic values and processing. Trends in Food Science \& Technology, v.89, p.76-87, 2019. https://doi. org/10.1016/j.tifs.2019.05.008

CLIMA-DATE.ORG. Rio do Sul Clima (Brasil). Available in: https://pt.climate-data.org/america-do-sul/ brasil/santa-catarina/rio-do-sul-999174/\#: :text=Rio\%20 do\%20Sul\%20tem\%20uma,m\%C3\%A9dia\%20anual\%20 \%C3\%A9\%201529\%20mm Accessed on: Sept., 2020.

CORRÊA, V.G.; TURECK, C.; LOCATELI, G.; PERALTA, R.M.; KOENHLEINE, A. Estimate of consumption of phenolic compounds by Brazilian population. Revista de Nutrição, v.28, n.2, p.185-196, 2015. https://doi. org/10.1590/1415-52732015000200007

CORTEZ, R.; LUNA-VITAL，D.A.; MARGULIS，D.; MEJIA, E.G. Natural pigments: stabilization methods of anthocyanins for food applications. Comprehensive Reviews in Food Science and Food Safety, v.16, n.1, p.180-198, 2017. https://doi.org/10.1111/1541-4337.12244

COSTA, L.C.; RIBEIRO, W.S.; BARBOSA, J.A. Compostos bioativos e alegações de potencial antioxidante de flores de maracujá, cravo amarelo, rosa e capuchinha. Revista Brasileira de Produtos Agroindustriais, v.16, n.3, p.279-289, 2014. https://doi.org/10.15871/1517-8595/ rbpa.v16n3p279-289

FERNANDES, L.; CASAL, S.; PEREIRA, J.A.; SARAIVA, J.A.; RAMALHOSA, E. Edible flowers: a nutritional perspective. Acta Portuguesa de Nutrição, v.6, p.32-37, 2016. https://doi.org/10.21011/apn.2016.06

GONÇALVES, J.; SILVA, G.C.O.; CARLOS, L.A. Compostos bioativos em flores comestíveis. Revista Perspectivas Online: Biológicas e Saúde, v.9, n.29, p.1120, 2019. https://doi.org/10.25242/886892920191719

GONZÁLEZ-BARRIO, R.; PERIAGO, M.J.; LUNARECIO, C.; GARCÍA-ALONSO, F.J.; NAVARROGONZÁLEZ, I. Chemical composition of the edible flowers, pansy (Viola wittrockiana) and snapdragon (Antirrhinum majus) as new sources of bioactive compounds. Food Chemistry, v.252, p.373-380, 2018. https://doi.org/10.1016/j.foodchem.2018.01.102

INSTITUTO ADOLFO LUTZ. Métodos físico-químicos para análise de alimentos. 4. ed. São Paulo: Instituto Adolfo Lutz, 2008. 1020p.

ISLAM, S. Anthocyanin compositions in different colored gladiolus species: A source of natural food colorants. American Journal of Food Science and Technology, v.4, n.4, p.109-114, 2016. https://doi.org/10.12691/ajfst-4-4-4

LARA-CORTÉS, E.; MARTÍM-BELLOSO, O.; OSORIODÍAZ, P.; BARRERA-NECHA, L.L.; SÁNCHES-LÓPEZ, J.A.; BAUTISTA-BAÑOS, S. Actividad antioxidante, composición nutrimental y funcional de flores comestibles de dalia. Revista Chapingo Serie Horticultura, v.20, n.1, p.101-116, 2014. https://doi.10.5154/r.rchsh.2013.07.024

LEE, S.K.; KADER, A.A. Preharvest and postharvest factor influencing vitamin $\mathrm{C}$ content of horticultural crops. Postharvest Biology and Technology, v.20, n.3, p.207-220, 2000. https://doi.org/10.1016/S0925-5214(00)00133-2

LI, A.N.; LI, S.; LI, H.B.; XU, D.P.; XU, X.R.; CHEN, F. Total phenolic contents and antioxidant capacities of 51 edible and wild flowers. Journal of Functional Foods, v.6, p.319-330, 2014. https://doi.org/10.1016/j.jff.2013.10.022

LIM, T.K. Edible medicinal and non-medicinal plants: Flowers. Dordrecht: Springer, 2014. 1024p. https://doi. org/10.1007/978-94-007-7395-0

MATRASZEK-GAWRON, R.; CHWIL, M.; TERLECKA, P.; SKOCZYLAS, M.M. Recent studies on anti-depressant bioactive substances in selected species from the genera Hemerocallis and Gladiolus: A systematic review. Pharmaceuticals, v.12, n.4, p.172, 2019. https://doi. org $/ 10.3390 / \mathrm{ph} 12040172$ 
MLCEK, J.; ROP, O. Fresh edible flowers of ornamental plants - A new source of nutraceutical foods. Trends in Foods Science \& Technology, v.22, n.10, p.561-569, 2011. https://doi.org/10.1016/j.tifs.2011.04.006

MOREIRA, M.C.N.D.; ALMEIDA, G.L.; CARVALHO, E.E.N.; GARCIA, J.A.; NACHTIGALL, A.M.; BOAS, M.V. Pétalas de rosa vermelha para uso na alimentação humana. Alimentos: Ciência, Tecnologia e Meio Ambiente, v.1, n.6, p.134-149, 2020.

NAVARRO-GONZÁLEZ, I.; GONZÁLEZ-BARRIO, R.; GARCÍA-VALVERDE，V.; BAUTISTA-ORTÍN， A.B.; PERIAGO, M.J. Nutritional composition and cntioxidant capacity in edible flowers: characterisation of phenolic compounds by HPLC-DAD-ESI/MS. International Journal of Molecularv, v.16, n.1, p.805-822. 2015. https:// doi.org/10.3390/ijms16010805

SAVI, P.R.S.; SANTOS, L.; GONÇALVES, A.M.; BIESEK, S.; LIMA, C.P. Análise de flavonoides totais presentes em algumas frutas e hortaliças convencionais e orgânicas mais consumidas na região Sul do Brasil. Demetra: Alimentação, Nutrição e Saúde, v.12, n.1, p.275-287, 2017. https://doi.org/10.12957/ demetra.2017.22391

SCHWAB, N.T.; UHLMANN, L.O.; BECKER, C.C.; TOMIOZZO, R.; STRECK, N.A.; BOSCO, L.C.; BONATTO, M.I.; STANCK, L.T. Gladíolo: fenologia e manejo para produção de hastes e bulbos. Santa Maria: Pallotti, 2019. 136p.
SILVA, E.N.; CRUZ, R.R.P.R.; RIBEIRO, L.S.; PIMENTEL, A.T.; SOARES, C.R.D.M; MELO, J.F.S.; SILVA, J.G.; RIBEIRO, W.S. Determinação do ponto de colheita de flores de Tropaeolum majus L. Revista Brasileira de Agropecuária Sustentável, v.8, n.1, p.3743, 2018. https://doi.org/10.21206/rbas.v8i1.436

SKRAJDA, M.N. Phenolic compounds and antioxidant activity of edible flowers. Journal of Education, Health and Sport, v.7, n.8, p.946-956, 2017. https://doi. org/10.5281/zenodo.995637

STEFANIAK, A.; GRZESZCZUK, M. Nutritional and biological value of five edible flower species. Notulae Botanicae Horti Agrobotanici, v.47, n.1, p.128-134, 2019. https://doi.org/10.15835/nbha47111136

SURAM, S. Research Trends in Food Technology and Nutrition. Rohini: AkiNik, 2020. v.6. 176p.

TAKEMURA, T.; TAKATSU, Y.; KASUMI, M.; MARUBASHI, W.; IWASHINA, T. Anthocyanins of gladiolus cultivars and their contribution to flower colors. Journal of the Japanese Society for Horticultural Science, v.77, n.1, p.80-87, 2008. https://doi.org/10.2503/jjshs1.77.80

UHLMANN, L.O.; BECKER, C.C.; TOMIOZZO, R.; STRECK, N.A.; SCHONS, A.; BALEST, D.S.; BRAGA, M.S.; SCHWAB, N.T.; LANGNER, J. Gladiolus as an alternative for diversification and profit in small rural property. Ornamental Horticulture, v.25, n.2, p.200-208, 2019. https://doi.org/10.14295/oh.v25i2.1541 